\title{
Pulling together and tearing apart - The occupational branding of public relations and the management of tainted work
}

Public Relations Inquiry 2017, Vol. 6(I) 73-98

(C) The Author(s) 2017

Reprints and permissions: sagepub.co.uk/journalsPermissions.nav DOI: 10.1 177/2046|47X16682986 journals.sagepub.com/home/pri

@SAGE

\section{Christina Grandien}

Mid Sweden University, Sweden

\begin{abstract}
This article is a critical exploration of the professionalization of public relations as a struggle or contest over the meaning of work, and it engages with a question about the driving forces behind the long-standing professional project of public relations. The article will use the concepts of 'dirty work' and 'occupational branding' to address the relation between the role actually performed, normative ideals, and the image of the occupation. The article analyzes op-eds authored by public relations practitioners, scholars, and representatives from professional organizations in newspapers and trade media in order to explore the ways in which the meaning of public relations work is described, contested, and framed, and, consequently, the occupational brand of public relations is formed.
\end{abstract}

\section{Keywords}

Dirty work, identity, occupational branding, professionalization, public relations practitioners

\section{Introduction}

This article is a critical exploration of the professionalization of public relations (PR) as a struggle or contest over the meaning of work (Ashcraft, 2013; Ashcraft et al., 2012),

\section{Corresponding author:}

Christina Grandien, Department of Media and Communication, Mid Sweden University, Holmgatan I0,

SE-85I 70 Sundsvall, Sweden.

Email: christina.grandien@miun.se 
and it engages with a question about the driving forces behind the long-standing professional project (Larson, 1979) of PR. The article will use the concepts of 'dirty work' (Hughes, 1951, 1958, 1962) and 'occupational branding' (Ashcraft et al., 2012) to address the relation between the role actually performed, normative ideals, and the image of the occupation. The article analyzes op-eds authored by PR practitioners, scholars, and representatives from professional organizations in newspapers and trade media in order to explore the ways in which the meaning of PR work is described, contested, and framed, and, consequently, the occupational brand of PR is formed.

Professionalization has been a general theme of the research about PR and the industry is often described as going through a process of professionalization (Grunig, 2000), with the overarching goal of paving the way for the collective mobility and social advancement of the occupation (Bolton and Muzio, 2008). However, despite substantial efforts to try to convince others of the value and contribution of PR to organizations and to society, PR still suffers from an experienced absence of recognition from others (Larsson, 2007). For an occupation, this state reinforces the call for further pursuing actions that can lead to higher societal validation (Alvesson, 2013). PR practitioners are serving the interests of business organizations, non-profits, as well as governments at the same time as they are obliged to serve the public interest. These sometimes conflicting interests of PR have led to substantial debates and discussions among scholars and practitioners over the core function and the fundamental values of PR (Fitzpatrick and Bronstein, 2006). There is also a present and historical struggle about coming to terms with 'the nature and social role of their practice's ethical implications and connections with propaganda and the associated historical baggage' (L'Etang, 2006: 40). In a study based on a nationwide Swedish survey, PR was found at the very bottom of the list of trustworthy occupations (Larsson, 2004). One conclusion from that study is that a profession engaged in advocating the interests of various organizations will evoke suspicion and distrust in the eyes of the public. Also, research about media representations of PR is summarized by Edwards and Pieczka (2013) as painting 'a fairly consistent picture of PR as a somewhat shady practice of manipulation and lies at worst, image and reputation management at best' (p. 9). Swedish media reporting of corporate scandals and compromising events that involve PR practitioners creates a pent-up need for defending the occupation against an increasingly bad reputation and to gain a more positive occupational image. According to Tyllström (2013), the Swedish PR industry is showing several signs of suffering from a stigma due to sticky negative connotations, resulting in practitioners distancing themselves from the PR label. Svallfors (2016) argues that Swedish policy professionals are hesitant to enter the PR industry, in spite of the fact that this would be the most economically rewarding way to use their political skills, since it is 'a place for cold-hearted calculations and moral spinelessness' (p. 68).

In order to achieve a valued occupational identity, members of an occupation try to create a positive image of their role and work, an image that can be damaged or undermined when tasks that are incompatible with the claimed identity must be performed (Morales and Lambert, 2013). Tasks that are potentially harmful to the image of an occupation can be conceptualized as 'dirty work' (Hughes, 1951, 1962), and are the tasks that contradict what the occupation 'normatively defines as its pride and virtue, and therefore threaten to shatter the fragile image the occupation puts forward for itself and its 
members' (Morales and Lambert, 2013: 229). The concept of dirty work is in itself a social construction where 'dirtiness' is not inherent in the work itself but imputed by people (Ashforth and Kreiner, 1999). Dirty work occupations are typically described as being physically, socially, or morally tainted in one or several ways (Hughes, 1958). Accordingly, PR can be described as a socially and morally tainted occupation that has faced difficulties in attaining societal validation (Ashforth and Kreiner, 1999) since taint reduces the prestige of the occupation and stigmatizes practitioners (Drew et al., 2007). According to Kreiner et al. (2006), PR represents an occupation where only some tasks are stigmatized. Fawkes (2012) describes the competing identities of PR as a tension between the saintlier oriented ethical guardian with public good at heart, and the sinful advocate promoting special interests. PR can thus be seen as an occupation associated with some morally dirty components but where clean components compensate for, or compete with, the dirty ones. The concept of dirty work has been applied to a wide range of occupations but research on occupations where only a small part of the job is considered as dirty work is a neglected area within research (Rayner et al., 2014).

According to Ashcraft et al. (2012), a branding lens can be productive when analyzing professionalization. It emphasizes collective identity work as a core professionalization activity and acknowledges how such an activity creates obvious or habitual associations between a line of work and a condensed image of what the occupation stands for among stakeholders and the public. The image problem of PR can thus be described as an identity project with the goal of attaining an occupational brand that conveys an association between PR work and the condensed image of it. This conceptualization highlights and activates the interplay between occupational identity and image, often characterized by power games played by a variety of sub-groups (Vásquez et al., 2013). Acknowledging and analyzing the moral taint associated with the occupation in relation to collective identity work lends an opportunity to acknowledge the ways in which occupational taint reduces the prestige of the occupation (Drew et al., 2007) and intensifies the need for occupational branding as a professionalization activity.

\section{Theoretical background}

\section{The professionalization of PR}

Undoubtedly, the occupation of PR has gone through some development and growth over the past decades. The body of knowledge is growing, specialized PR educations are increasing (Van Ruler and Verčič, 2008), and professional organizations are expanding as well as contributing to the development of occupational roles and to the enforcement of professional ethics endorsed through membership. Practitioner autonomy has also been growing over the past decades, perhaps most visibly through the increasing legitimacy of communication managers (Johansson and Ottestig, 2011) and of practitioners evolving from being information producers to communication strategists (Grunig, 2006). According to Verhoeven et al. (2011), the management of communication processes has been institutionalized in all kinds of organizations in Europe over the past few decades as the management of communication processes. Frandsen and Johansen (2010) describe PR as an ambitious profession wanting to promote practitioners as communication managers or 
communication executives. Furthermore, the role of PR as a contributor to the public interest through the spreading of knowledge, truth, and dialogue adds to the conception of altruism (Kent and Taylor, 2002).

There are, however, limitations to the professionalization of PR. A formal degree in PR is not required to practice within the field. Perhaps there is even a partially opposing movement where practitioners from other backgrounds than PR are pursuing careers within the industry (Pieczka and L'Etang, 2006). PR cannot claim to be providing a unique and essential service differentiated from other services, both due to the non-requirement of a degree in PR but also because of the erosion of the boundaries to other occupations. The industry of PR is incorporating new occupational roles and tasks and adjacent occupations are claiming ownership of the same roles and tasks. According to L'Etang (2004), delineated boundaries to other occupations are important for practitioners to be able to articulate their area of expertise and control the market for their services. L'Etang (2004) further argues that there are revolving doors between journalism, PR, think tanks, and the civil service, which signals a difficulty of establishing a clear jurisdiction for the practice. Jahansoozi (2006) suggests that marketing practitioners are attempting to own and rebrand PR, subsuming it into technical marketing communication.

According to Fitch and Third (2013), the feminization of public relation has resulted in attempts to ensure professional status for PR by positioning it as a strategic and corporate activity, which continues to shape the identity of PR (Fitch \& Third). This development has, however, resulted in a situation where women are more likely to work with, for example, internal relations, publicity, and event management and men in media relations, political and government communication, and more closely aligned with strategic and management activity (Fitch and Third, 2013; Fitch et al., 2016; L'Etang, 2015). L'Etang (2015) further suggests that PR is a historically gendered occupation since women used to possess backstage roles where interpersonal, communication, administrative, and organizational skills were typical, supporting the men who were fronting the occupation. In that sense, PR can be seen as an industry where professional norms are constructed in light of the involvement of White, middle-class men, and will hence have gender, class, and ethnic dimensions (Muzio and Tomlinson, 2012). It can be argued that the feminization of PR has resulted in a division between professional and strategic management activity and non-professional, technical activity such as publicity and promotion (Fitch and Third, 2010). The exclusion of women from managerial positions stems from the inclusion of women in support roles and from the construction of masculine executive knowledge contrasted with feminized middle management knowledge (Ashcraft et al., 2012).

Also, codes of professional ethics of PR are voluntary, and, since most are often issued by the professional organizations, they only apply to members and do not constitute an ethical basis for decision-making (Fitzpatrick and Gauthier, 2001).

Many issues related to the professional project of PR are still unsettled. One major obstacle is the lack of professional credibility and legitimacy among the general public. Accordingly, a public discussion about the practice, the standards, and the occupation outside of associations and professional circles can increase the legitimacy of PR (Valentini, 2009). Professional projects, however, require persistent tactical campaigns that capitalize on resources that appeal to, for example, ethical standards and the public 
interest in order to portray claims and privileges in a more attractive manner (Bolton and Muzio, 2008).

\section{$P R$ as a tainted occupation}

The term 'dirty work' refers to occupations or tasks that are physically, socially, or morally tainted (Ashforth and Kreiner, 1999; Hughes, 1958). Occupations that are physically tainted are defined by being associated with apparent offensive things or performed under highly dangerous conditions. Socially tainted occupations involve regular contact with stigmatized populations or having servile relationships built into the structure of the occupation. Morally tainted occupations are regarded as sinful or of dubious virtue by the society or are known for commonly using deceptive or intrusive methods (Ashforth and Kreiner, 1999).

According to Rayner et al. (2014), research on occupations where only a small part of the whole job is considered as dirty work is a neglected area within research. This reveals a previous limitation of dirty work research as too narrowly defining dirty work occupations. The concept of dirty work has been applied to a wide range of occupations, but studies of PR as a dirty work occupation remain underexplored. PR is an occupation where only some tasks are stigmatized (Kreiner et al., 2006) while practitioners enjoy high levels of cultural and social capital (Edwards, 2008) and symbolic power (Edwards, 2009; Ihlen, 2007); taint, however, reduces the prestige of the occupation and stigmatizes practitioners (Drew et al., 2007).

Dirty work is contextually bound and socially constructed and will hence vary across occupations. What is considered to be dirty work lies in the eye of the beholder rather than being an objective state (McMurray and Ward, 2014). Labeling PR as dirty work, per se, may seem presumptuous, but recent research has underlined the need to map a broader landscape of stigmatized work and that some kind of dirty work can be found in almost all occupations (Kreiner et al., 2006). PR can, in some respects, be identified as a low-intensity dirty work occupation that is morally tainted.

In an article from 2006, Kreiner et al. introduced a typology of occupational dirty work (see Figure 1) that varied on two dimensions: the breadth and depth of the perceived dirtiness. Breadth captures the proportion of the work that is dirty and the centrality of the dirt to the occupational identity. The depth dimension refers to the intensity of the dirtiness and the extent to which someone, who is part of the occupation, is directly involved in the dirty work. Commonly, only occupations that score high on both the breadth and depth dimensions are considered dirty, but expanding the notion of dirty work occupations allows for a better understanding of how stigma dynamics play out in different occupational contexts.

According to Kreiner et al. (2006), PR can be seen as an example of an occupation suffering from a 'compartmentalized stigma' (p. 622), where only some tasks are stigmatized or tainted and where the primary source of the stigma is morally tainted work. The characteristic of a compartmentalized stigma is that the depth of taint is high but the breadth is low. Occupations that have a compartmentalized stigma are not likely to be perceived by society as dirty per se, unless the tainted component is highly salient to the public. Due to the high depth of the taint, occupational members will be motivated to come to grips with the taint. At the same time, there is a relatively mild external threat. 


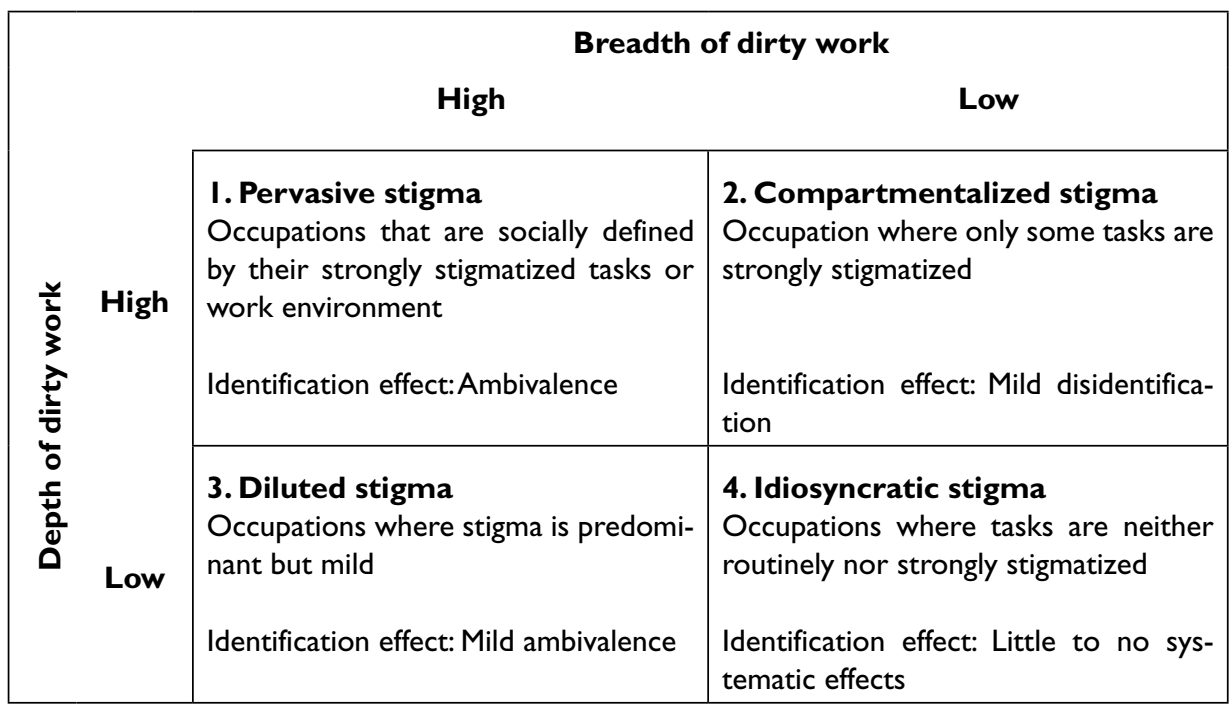

Figure I. A typology of occupational dirty work.

From 'Identity dynamics in occupational dirty work: Integrating social identity and system justification perspectives' by GE Kreiner et al. (2006).

Because of the low breadth, there is a low driving force for the occupation to form a coherent unity and hence the defenses are more individualistic than shared. Tainted tasks are labeled as separate from the overall occupation, which distances the practitioner from the tainted tasks rather than from the occupation itself. Refocusing and distancing itself from stigmas is the most common defense tactic in this type of occupations (Kreiner et al., 2006).

\section{The branding of a tainted occupational identity}

In this study, I argue, in line with the work of Ashcraft (2013) and Ashcraft et al. (2012) that the main mechanism of professionalization is the struggle or contest over the meaning of work. This contest takes place in, for example, occupational associations, educational institutions and, of interest to this study, in venues for popular and public discourse. Professionalization can be seen as an occupational identity project characterized by both controversy and agreement about what practitioners actually do (or should do), what practitioners want others to think they do, and what individual practitioners make of their own individual identity within the occupation.

In this article, occupational identity will be conceptualized as a 'collective essence or personality of a line of work' (Ashcraft, 2013: 8). Ashcraft (2013) argues that its specific features can distinguish an occupation, and that work becomes known in relation to the social identities associated with the occupation. An occupation can be seen as constructed through communication and enacted through communicative processes that involve multiple actors and institutions, occurring at micro- and macro-levels and taking place across 
time and space (Ashcraft, 2007). Interaction produces and reproduces occupational identities and forms a discourse of what it means to be part of a specific occupation. In that sense, an occupation is a communicative construct (Ashcraft, 2007) that is enacted through discursive formations that are materially manifested in objects, sites, and bodies (McDonald, 2010). Dominant discourses about what it means to belong to an occupation can be reproduced through interactions over time and space, between actors and institutions. Tensions can also cause dominant discourses to be challenged by counter-discourses and eventually produce new occupational identities. Research about occupational identity also highlights that society shapes which occupations are accepted and that identities are formed through social approval (Phelan and Kinsella, 2009).

Attaining a positive occupational identity or a high occupational esteem can be problematic for dirty work occupations and one strategy can be to assume values that are perceived to be socially attractive. Groups of dirty workers 'may espouse socially desirable values and beliefs as an impression management tactic directed at external audiences' (Ashforth and Kreiner, 1999). For PR, emphasis on socially attractive values and beliefs can, along with other purposes, be seen as a way of branding the occupation in order to achieve higher professional status in the eyes of external audiences. Moreover, given the lack of trust that the public ascribes to PR (Larsson, 2007), there is a need to reposition PR as less morally stained. Over the years, the morality of PR practitioners has been criticized and challenged by both people within the occupation and by the public, and research also suggests that PR suffers from an image problem (Holtzhausen and Voto, 2002). The image problem of PR displays ambiguities about what practitioners should do, what they actually do, what others think they should do, and about the individual sense of belonging within the occupation. Consequently, the professionalization of PR may perhaps be inhibited by different interpretations of what the collective personality or essence of PR actually represents. Work becomes known in relation to the social identities displayed by practitioners associated with the occupation.

According to Alvesson (2000), professions are a very strong source of social identity, but to a lesser degree when it comes to knowledge-workers that do not belong to a fully recognized profession. Social identity theory suggests that once a person has defined themselves as being part of a social category, individuals seek to positively differentiate their group from other groups (Tajfel and Turner, 1979) and strive to see 'us' as better than and different from 'them' (Cornelissen et al., 2007; Turner et al., 1994). The aim of differentiation from other groups is to maintain or achieve superiority on some dimension, and the actions are therefore essentially competitive (Tajfel and Turner, 1979).

\section{The management of tensions in the occupational branding of $P R$}

Practitioners can make meaning of, or frame, their work and occupation by managing and maintaining material and discursive tensions. This process can be seen as a social process in which occupational identities are negotiated over time. In that sense, occupations are not stable units; rather, they are exposed to influences from both inside the organizations and from society (Meisenbach, 2008).

Research about these tensions has become a prominent theme within organizational communication studies (Andriopoulos and Lewis, 2009; Fairhurst and Putnam, 2004; 
Seo et al., 2004; Trethewey and Ashcraft, 2004) and tensions are present within both traditional organizational boundaries, but also in occupations (Meisenbach, 2008). Meisenbach (2008) has further argued that the tensions present in occupations are affecting the construction and negotiation of occupational identities.

Tensions have traditionally been viewed as problems, ruptures, or flaws but, as Putnam and Fairhurst (2015) highlight, the regular occurrence of them signals that they the need to be theoretically embraced as ways of both facilitating and restricting organizing processes (cf. Pepper and Larson, 2006; Seo et al., 2004; Trethewey and Ashcraft, 2004). According to Putnam and Fairhurst (2013), organizational processes often move in opposite or competing directions, creating tensions. The presence of competing directions can cause push-pull dilemmas and evolve into contradictions or paradoxes as they develop through different relationships (Fairhurst and Putnam, 2004).

To summarize, the image problem of PR can be analyzed as a struggle or contest over the meaning of work (Ashcraft, 2013; Ashcraft et al., 2012) that is often characterized by power games played by a variety of sub-groups (Vásquez et al., 2013) where occupational identities are negotiated over time. However, the moral taint of an occupation may imply the advocacy of values and beliefs that are perceived to be socially desirable. Against this background, the purpose of this study is to explore the occupational branding of PR and the management of tainted work. The article analyzes op-eds authored by PR practitioners, scholars, and representatives from professional organizations in newspapers and trade media in order to further understand the ways in which the meaning of PR work is described, contested, and framed, and hence constructs the occupational brand of PR. The purpose of the article will be addressed through the following research questions:

$R Q 1$. What are the major dilemmas or tensions occurring in relation to the occupational branding of PR and what actors are engaged?

$R Q 2$. In which ways do $\mathrm{PR}$ practitioners assign meaning to work in written op-eds?

$R Q 3$. How do PR practitioners manage the tainted work associated with their professional identity and occupation?

\section{Method}

The contest over the meaning of work takes place in, for example, occupational associations, educational institutions, and in venues for popular and public discourse. The media is also an important venue for popular and public discourse, where the struggle or contest over the meaning of work takes place. On the opinion pages of regular newspapers and trade media, PR practitioners, professional organizations, and scholars occasionally write op-eds that deal with various issues related to the occupation. The opinion pages are often among the most read sections of a publication and an attractive way to place an issue in the public eye or to promote a certain value or issue to the readers of that publication. Opinion pieces or op-eds authored by PR practitioners, scholars, and representatives of professional organizations can be seen as mediated outputs for the identity work 
Table I. Sample.

\begin{tabular}{llc}
\hline Outlet & Description & No. of texts \\
\hline Dagens Nyheter & Leading Swedish daily newspaper & 6 \\
Svenska Dagbladet & Leading Swedish daily newspaper & 8 \\
Aftonbladet & Leading Swedish tabloid newspaper & 8 \\
Expressen & Leading Swedish tabloid newspaper & 1 \\
Resumé & Trade media newspaper & 16 \\
Dagens Media & Trade media newspaper & 47 \\
\hline
\end{tabular}

of PR, which reflects the competing demands or tensions concerning which values are essential to the occupation. One output for identity work of PR practitioners is mediated issue arenas (Luoma-aho and Vos, 2010) where means of expressions are not interpreted or angled by a journalist. In opinion pieces, both in regular newspapers and trade media, PR practitioners and scholars have an opportunity to address industry-related issues in their own words. In the process of constructing a collective occupational identity, or an occupational brand, these self-presentations represent how professionals want to be understood, what they see as important aspects of the identity of the profession and how they choose to construct legitimacy without being interrupted. Accordingly, these opinion pieces and op-eds are a piece of the puzzle in a branding process that activates the interplay between occupational identity and image, and occupational branding is accomplished without stakeholders formally referring to their activities as branding (Vásquez et al., 2013). The public image of PR is also to some extent mediated, meaning that people depend on the media as the most important source of information (cf. Strömbäck, 2008). Accordingly, media representations of PR can influence the public perception of the occupation.

The study draws on opinion pieces from Swedish news media and the PR trade media. They were collected through the websites of each outlet and the selection was limited to opinion pieces written by PR professionals. The search was conducted through using a number of words like 'PR professional', 'PR', 'PR agency', 'communication professional', 'communication industry', 'communication department', and 'communication'. Thereafter, all search hits were reviewed and selected on the basis of who authored it. The sample consists of a total of 86 articles. The number of articles from the news media is 23, published between October 2009 and October 2014. The newspapers selected for the study are the four largest in terms of circulation in Sweden, two tabloid newspapers and two morning newspapers. The trade media is represented by two newspapers, and the sample consists of 63 articles, published between September 2008 and June 2015. The two trade media newspapers are aimed at a broad audience of communicationrelated professionals, including advertising, marketing, and PR professionals. All units of analysis were retrieved from the websites of each newspaper (see Table 1 for the presentation of the sample).

As the selection turned out, a majority (64) of the opinion pieces were written by PR consultants. In one case, the opinion piece was written by one person representing an agency and one from a university, and, in another case, the author represented both an 
agency and a school of communication. Six articles were written by representatives from professional organizations, 3 by PR practitioners working for private organizations, 4 by PR scholars, and 1 by a PR student. No less than 49 articles had a single author, and, with respect to the pieces with multiple authors, there were 9 articles where the authors represent multiple organizations.

The collected texts represent multiple PR oriented organizations, but, clearly, some agencies are overrepresented (or very active in writing opinion pieces). At the extreme end is one particular agency - Westander -, which is responsible for 30 texts in total, which makes it by far the most frequently represented actor. The texts are spread out over 8 years; 3 texts in 2008, 19 texts in 2009, 6 texts in 2010, 10 texts in 2011, 16 texts in 2012, 9 texts in 2013, 10 texts in 2014, and 13 texts in 2015.

After all the texts had been retrieved, they were assembled in a document where the dates of publication, the name of the newspaper, the authorship, the organizational belonging, and the heading of the text were documented.

The study used a qualitative content analysis to thematically analyze the content of opeds written by PR practitioners. More specifically, the study used textual analysis, which seeks to understand the underlying meanings and themes in the material (Fürsich, 2009). Textual analysis is, according to McKee (2003), a way for researchers to gather information about how people make sense of the world, of who they are and how they fit into the world they live in. It allows us to see how similar or different the sense-making practices that different people use can be. Texts in this context are seen as 'the material traces that are left in the practice of sense-making' (McKee, 2003: 15). Accordingly, I try to identify latent themes that reflect issues concerning PR professionalism and tensions over what constitutes PR work. After a first reading of the texts, the main theme(s) for each text were summarized in a document. Thereafter, a close reading of each text was conducted with the purpose of identifying reoccurring patterns and themes. The texts were thematically organized and read again in order to refine and reorganize the themes and identify tensions. Four major themes were identified in the material and they were about 'Wages and working conditions', 'occupational boundaries', 'professional norms', and 'occupational myths'. Furthermore, a more detailed analysis was conducted in order to examine how perspectives and accounts were constructed in order to be persuasive and credible. Finally, quotes were used to elucidate the substance of each theme and to ease the understanding of the results. The processing of the material was carried out in the Swedish original versions of the texts and illustrative quotations were translated into English.

\section{Results}

The results will be thematically addressed through the most salient themes that display tensions related to occupational identity that were seen in the material. However, with respect to some of the themes, the original op-ed was followed by several responses in the same media outlet. In one case, for example, the same issue was debated in five subsequent op-eds. These micro-debates rarely make up a whole theme. Rather, some key issues appear with regularity and in some cases they stir up reactions from other actors that reply. Most of the themes highlighted below were spread over the whole time period analyzed, but intensified on some occasions. 


\section{Wages and working conditions: internal or external responsibilities}

The first theme addressed focuses on wages and working conditions in the PR industry: will better working conditions increase quality of work or is it the contribution to society and democracy that improves work quality? PR can be seen as a product of both democracy and capitalism and has far reaching effects on society (Holtzhausen, 2000). The image of PR as a high-wage industry profiting from furthering special interests or increasing the influence of large corporations (Ihlen and Verhoeven, 2012) is, however, problematic in terms of occupational prestige and legitimacy, since it reflects and reinforces the moral stigma of the occupation. Research shows that one common justification for dirty work is to describe the occupational mission in value-laden terms (Ashforth and Kreiner, 2014). This theme displayed how responses to a call for better working conditions for practitioners were opposed by emphasizing PR's important role in the public sphere.

This theme only played out in the trade media and one agency predominated the discussion, with 8 texts out of the 11 on the topic. These op-eds were spread out between 2008 and 2012, with one micro-debate starting in late 2011 and continuing in 2012.

The texts from the predominating agency talked about the need to raise the hourly rates for consultants in order to secure quality and the need to discard the overtime culture that, according to these op-eds, characterizes the industry in Sweden. The texts positioned the agency as a responsible employer that sets an example for the industry:

Too many PR agencies sell their services at too low rates. This is unfortunate from several perspectives, not just the owners'. Agencies with a good economy easier become long-term partners for their clients and a stable employer. Price-cutting agencies, on the contrary, end up in a downward spiral of short-term actions and declining quality. (Many are selling at too low rates, Resumé, 20 January 2011)

The same agency also wrote about how the industry completely failed to charge for increased efficiency, which they predict will result in competence drainage, low salaries, and competitive disadvantages toward other knowledge occupations:

It is likely that this unhealthy overtime culture contributed to the stagnating agency income per employee and stagnant wages within the public relations industry./ ... /Our philosophy is that you should be able to have a fun, responsible and demanding job without having to work overtime. (Work less and charge more, Resumé, 22 September 2012)

Responding op-eds, however, highlighted that increased wages are not the solution. The respondents argued that the industry needed to take on greater responsibilities toward helping organizations with lesser resources, and an effort to maximize profits will prevent that from happening since hourly rates may result in the exclusion of clients with lesser resources. Also, the responding op-eds argued that instead of focusing on hourly rates and time reporting, the focus should be on increasing efficiency. If that happens, PR will thus have had a negative impact on democracy by letting economic resources set limits for which voices get to be heard. The quote below illustrates how one of the responding op-eds counters the argument for more pay: 
The professionalization of lobbying and communication risks leading to the exclusion of those who cannot afford these services. This is likely to lead to a public debate that is impoverished and characterized by stupidity instead of diversity. (PR agencies need to do more good do not charge more, Resumé, 18 August 2011)

Another op-ed argued that a focus on charging clients by the hour will lead to poor decision-making:

My experience is that when the agency focuses on the hours they can charge the client, they take worse decisions. Employees feel chased to bring in 'their hours' each week and consequently often do things that do not really create any value at all for the client. (You don't need to raise your prices, Dagens Media, 14 August 2012)

In the case of Sweden, the overtime culture within the industry is a well-known problem, and addressing it through suggesting higher incomes per employee is an opportunity for other agencies to downplay the high-wage and profit-making image of the occupation and instead emphasizing societal responsibility and quality.

Establishing the status of being professionals, however, entails both a pay that matches the unique qualities and services that the occupation claims to deliver, as well as serving the public interest, contributing to democracy, and paving the way for the collective mobility and social advancement of the occupation (Bolton and Muzio, 2008). This displayed how practitioners through value-loaded moral arguments maintain a tension between externally oriented societal responsibilities and internally oriented working conditions.

\section{Occupational boundaries: empowerment or disempowerment}

The second theme concerned the boundaries of the occupation against other occupations and both professional organizations and consultancies that addressed this. This theme contains a tension between the empowerment or disempowerment of PR practitioners. Empowerment as described in the op-eds, can be achieved through, for example, better education or more knowledge, but can also be dismantled when people from other occupations enter PR. It also displays a dilemma where practitioners need more knowledge about, for example, media logic, politics, and social media in order to advance the standing of the occupations, but the inclusion of, for example, ex-journalists or ex-politicians jeopardizes the reputation of the occupation even if these people contribute something of high value in terms of knowledge.

Kreiner et al. (2006) propose that the prime tactic for occupations suffering from a compartmentalized stigma will be to label the tainted tasks as distinct from the overall occupation. In the case of PR, one strategy in use appears, however, to be about distancing certain practitioners from the occupation itself in order to create a separation or to acquire better knowledge to deliver professional services. This strategy suggests that practitioners are trying to delimit the occupational boundaries to certain practitioners and instead acquiring the needed knowledge from within.

Op-eds, for example, addressed insufficient quality of university educations within the field of PR, where more collaboration with the industry and a more specialized education with specialized knowledge is called for. One op-ed talked about how Swedish 
agencies were establishing offices in Brussels, but that PR consultants lack the knowledge it takes to work in this environment. Another example concerns the need for PR practitioners to have better technical knowledge in order to work with digital media. Here, the empowerment of PR is about acquiring new competencies in order to keep up with societal developments. The threat of disempowerment lies in not having the right competencies for delivering the services that have been undertaken.

In terms of occupational boundaries, this theme deals with the 'revolving door syndrome', where, for example, journalists, advertising experts, and ex-politicians that work within the PR industry are blamed for devolving the value of PR. The voices that are raised highlight that other qualities are needed to work within the industry than what these neighboring occupations contribute. One example is an op-ed written by an exjournalist who recently started to work within the PR industry, but who is critical of the stream of journalists switching sides:

We who have been exhibitionist opinion-machines in the media world will have to accept that in the PR industry, the spotlight is on the client. As a relatively newly appointed entrepreneur in this particular industry that nowadays purchases used journalists, I actually find it difficult to see this recruitment as anything but expensive advertising for errant overpaid tellers of anecdotes set against a Potemkin back-drop. (Journalists make lousy PR consultants, Expressen, 5 November 2009)

This particular op-ed used very colorful language, and metaphors like 'Potemkin backdrop', in order to describe how the recruitment of journalists to PR agencies is nothing but a deceitful beautiful painting that is intended to conceal a poor reality behind a beautiful scenery. The quote from the op-ed also talks about how the use of ex-journalists can be seen as purchased expensive advertising for the occupation.

Another op-ed talked about the problems associated with politicians entering the PR industry. The article criticized a Swedish ex-prime minister who went to work for a large PR agency on the account of not being clear about which role he actually represents:

The exchange between politics and the PR industry is quite natural, because the same type of skills are required. Knowledge about the political system is needed on both sides, as well as the ability to interpret and influence public opinion. Both the politician and the lobbyist need to convince different people with different points of view. Knowledge of how the media works is moreover indispensable. At the same time, the roles are quite different. While the politician's job is to represent their constituents, to live up to election promises and to follow their ideological compass, the professional lobbyist is paid to represent their clients. (The lobbyist Göran is a danger to democracy, Aftonbladet, 20 December 2009)

In a larger context, the strategy of hiring ex-journalists and ex-politicians can be seen as way of trying to strengthen the brand of PR through the association with powerful or respected professionals from other occupations or acquiring the knowledge needed. But, on the other hand, the networks and the spotlights that these people bring along can also have the opposite effect since suspicions of improper use of networks and relations in politics and in the business sector will increase the image of PR as an unethical practice. 


\section{Professional norms: transparency or non-transparency}

Maybe the most salient theme in the material is a discussion about professional norms relation to the role of advocacy and influence in PR. This theme displays a tension about the right balance between transparency and non-transparency. In terms of dirty work, the accusations of the PR being about persuasion and deception, this theme relates to the core of the taint associated with PR. Some background to the issue about PR and transparency in Sweden is that there are very few agencies that work exclusively with lobbying or public affairs. Most agencies take on a range of different assignments, and advocacy or lobbying can be one of them. Also, lobbyists are not registered or accredited, and most Swedish agencies do not reveal which clients they are working with or lobbying for. Over the years, there have been a few legislative proposals with the aim of regulating transparency, in terms of when it comes to agencies disclosing who they work for, politicians disclosing which lobbyists they have been in contact with, and under what circumstances an ex-politician can work for a PR agency. One agency has positioned itself at the forefront of the issue of pursuing legislative change and the introduction of professional norms that enforce openness about clients. The professional association for PR agencies in Sweden, however, does not support the standpoint that client reporting should be enforced on all agencies.

Out of the 25 texts that touch on this theme, 16 were written by the same agency and they have a very distinct line of argument. The texts from this agency were consistently making use of words like 'social responsibility', 'democracy', and 'transparency' when talking about the need for agencies to be open about the clients that they represent and the issues that they are advocating for. The texts were published in both trade media and in national newspapers. A total of 10 out of the 25 texts were published in national newspapers, which makes the theme the least industry internal. The issue of lobbying and advocacy has also gained wide attention in the national media, even ignoring the texts looked at in this article.

Against this background, the issue about influence and advocacy can be considered a hot potato and a watershed moment in PR in Sweden. Apart from the one agency that has written the vast majority of the op-eds within this theme, other agencies have also written texts about the need for more openness and transparency in the industry in order to increase professionalism and to make a greater contribution to democracy:

There is, however, a different part of the communications industry where secrecy is the standard and not the exception, namely the increasingly important PR and lobbying industry. The professional associations that represent public relations consultancies have to this date ignored their social responsibility and instead formulated norms to protect large and covert lobbying firms. (Demand transparency about the advertising of the Swedish Democrats, Aftonbladet, 17 February 2010)

In another example, a group of consultants renounced the type of consultants who leave their moral compass at the doorstep. This op-ed came out of a media scandal commonly known as 'Primegate', which arose when a national newspaper published an article about how one Swedish PR agency had been hired by the Confederation of Swedish Enterprises to influence the Social Democratic party and get them to adopt more growth-friendly 
politics. Some of the consultants who worked on the assignment, however, were active members of the Social Democratic Party, and therefore, the agency was accused of lacking ethics and transparency:

We are fed up with the demonizing of the PR industry and want to show a different image, which we believe to be more representative than the one now described in the media. The vast majority of PR consultants do not leave their moral compass and integrity at the agency doorstep. Many of us would rather describe our job as involving an opportunity to work with the ultimate combination of having a professional approach and working on assignments that we stand behind and are passionate about. (We are fed up with the demonization of the PR industry, Dagens Media, 22 December 2010)

There is actually only one text that clearly counterbalanced the main line of argument that promotes more transparency. This piece argued that the correlation between secrecy and a lack of reliability does not exist and makes comparisons to the legal profession. The text instead pointed to the lack of understanding between the PR industry, journalists, and politicians as the major problem:

Why would the PR industry need different rules than consulting professions in general, such as the legal profession? Most consulting businesses keep parts of their client lists secret, and many also have an agenda that is not shared and openly communicated. Yet, their credibility is, generally speaking, much higher. (Hasty conclusions, Pontén, Dagens Media, 12 February 2009)

This rather large theme of unified voices, however, does not entirely represent an occupational group in agreement. First and foremost, the silence from 'the other side' can also be heard. In several of the texts, the authors called for reactions from the professional associations of PR consultancies and from a handful of prestige agencies that are known for their affiliations with prominent politicians and the largest companies and organizations in Sweden. These elite agencies were also accused of never disclosing anything about their clients and for hiring ex-prime ministers and top politicians. The call for a reaction from any of the above-mentioned agencies, however, was not met.

Despite the uniform choir promoting transparency and social responsibility, there is also some unease expressed about 'practicing what you preach'. In a couple of cases, the agency with the greatest number of op-eds within the theme replied to op-eds promoting transparency, openness, and disclosure of clients by saying that these agencies do not disclose who they are working with on different advocacy-related issues either. In other words, they criticize the authors of the other op-eds of preaching transparency but practicing secrecy. One example is an op-ed written by a former professor in political science who is now working for a PR agency. The professor writes about how the professional association needs to develop the regulations that govern the practice of PR:

Lobbyists should talk more openly about their business. But the publicity requirements should also apply to politicians and employees in the parliament and government offices. [...] A better documentation of contacts with lobbyist would enhance transparency and facilitate accountability. (Swedish lobbyists need ethical norms, Dagens Nyheter, 3 July 2012) 
In the reply to this op-ed, the predominating agency within this theme criticizes the former professor for not practicing what he preaches:

We agree with former political science professor Olof Petersson that the ethical standards of the PR industry today are not sufficient. There are, for example, absolutely no requirements from the professional association for PR agencies saying that agencies need to openly declare their ongoing lobbying campaigns when they are trying to influence political decisions. But Olof Petersson has every opportunity to lead by example. He is now tied to one of the largest PR agencies. Olof Petersson and Gullers Grupp should, in accordance with his argument, disclose the clients that they are lobbying on behalf of. Why wait? (Start by disclosing your own clients, Dagens Nyheter, 4 July 2012)

On the surface, the industry has shown a unified front saying that there is a need for stricter regulations, but a closer look reveals some tensions regarding the interpretations of what openness and transparency means. One major asset a PR agency can offer is discreetness and confidentiality toward clients. At the same time, one source of vulnerability is the suspicion of it engaging in unethical practices due to the discreetness and confidentiality. In terms of occupational branding, it could be considered destructive not to promote transparency since the public perception of the occupation is that it is all about secrecy and deception. But at the same time, it would be potentially bad for business for an agency to disclose the clients that they are working with since it would jeopardize both present and future clients. Consequently, the dilemma surrounding transparency and non-transparency appears like a double bind, or a trap between two unreasonable alternatives, which makes it hard to take action and move forward in the middle of the push-pulls of oppositional tensions (Putnam et al., 2014).

\section{Occupational myths: the individual practitioner and the occupation}

A number of texts address how to approach the bad image that the occupation struggles with. This theme is focused on how to kill the myths about PR, and how to better convey what PR really is. The assumption is that much of the criticism that the occupation is subjected to can be derived from how PR is misunderstood, undervalued, and oversimplified. One op-ed encouraged the agency that took on Julian Assange's case to let it go, since PR consultants have no place in lawsuits. Another op-ed promoted proactive PR and is critical of the key role PR experts have attained in managing situations where someone, or some entity, is experiencing a crisis of reputation, since it reinforces the image of the practitioners of PR as charlatans. A third example is an op-ed that criticized the ways in which PR experts advise senior managers to be less transparent and less accessible to the media, which the author sees as problematic. He compares the advice from PR experts to large companies to 'a North Korean strategy':

North Korea is a one-sided country. Sweden is not. It would therefore be interesting if Swedish media could team up and protest against the North Korean communications strategies that bad advisors gives large companies. (PR consultants advise increasingly North Korean, Resumé, 30 September 2013) 
Within this theme are several op-eds written in the wake of various organizational crises that have received widespread media coverage and have often involved poorly managed crisis communication. Here, all op-eds were written by PR consultants. In some cases, the op-eds were written as a result of PR consultants being accused of giving unethical advice to client organizations. These op-eds defended and distanced themselves from that specific conduct. One example comes from when one respected agency advised a local government on how to avoid media investigations by not talking to journalists, stalling the release of documents and information, and to only give very short answers to journalists. Mail conversations between a consultant and representatives from the local government leaked out to the press, and the PR agency was accused of encouraging violations of the law. One op-ed relating to this issue talked about how this event would haunt the rest of the industry and result in organizations being more hesitant about hiring consultants:

PR consultants are already a red rag to journalists. And now, in addition, JKL's e-mails will haunt us for many years. There serious thing about being haunted is not only that it gives the rest of the industry a bad reputation. That we would actually live with. Of a more serious nature is that it this perception of communication support is ultimately not good for democracy. (JKL's mail is haunting the PR industry, Dagens Media, 3 March 2015)

Other op-eds on the issue of media scrutiny dealt with how PR consultants were not to blame when organizations were failing in their crisis communication. The discussion was about how important it was that organizations hiring consultants actually listen to and act on the advice given by the consultants.

One notable aspect of this theme is that many of the op-eds start out by painting an image of PR as a tainted occupation and of how PR has become increasingly tainted due to different circumstances. Subsequently, the texts discuss how this image is not representative of the industry and go on to suggest different solutions for how the industry can distance itself from the tainted work. Also, the op-eds on this theme are less filled with the self-promotion of individual practitioners or specific agencies than the other themes. The strategy used in the context of this theme treats the bad image of the occupation as the result of the doings of individual practitioners and of individual agencies and different clients. In distancing themselves from and naming the sources of the bad image PR has, the problem is removed from the occupation itself. Shifting the blame, however, shows a dilemma where PR practitioners are forced to be on the defensive whenever something bad related to the occupation happens.

\section{Discussion}

On a general level, the results show an occupation where actors are pulling together at the same time as they are tearing apart. This dilemma is visible when, for example, practitioners address the same issue with more or less the same outlook, but are caught up in struggles over whose viewpoint is the most valid. At a glance, the struggles over the meaning of work displayed in these op-eds, depicts an industry where there is more disagreement than common ground. Op-eds, however, are designated to be argumentative and represent a certain viewpoint or perspective. 
Most of the op-eds retrieved for this article were written by consultants. This can be interpreted in at least two ways. First, consultants may feel a need to advertise their business since an op-ed highlighting the consultants or the agency's own greatness may result in good more business. For practitioners working in communication departments, the need for self-aggrandizement is perhaps not as urgent. Second, PR consultants, as a subgroup, are perhaps more morally tainted than PR practitioners working in organizations. The activities of PR consultants - through, for example, writing op-eds - can be seen as a means to wash away accusations that suggest moral shortcomings. According to Kreiner et al. (2006), occupations that suffer from a compartmentalized stigma are not likely to be perceived by society as dirty per se, unless the tainted component is highly salient to the public. According to research on the Swedish PR industry, practitioners are perceived by the public as one of the most untrustworthy occupational groups (Larsson, 2007) and the media attention to some issues associated with transparency and ethics has received wide public attention. Building on this, we can assume that the moral taint associated with PR is in some sense salient to the public. The taint associated with lobbying, transparency, and ethics is, however, mainly connected to the work of PR consultants, which can explain the overrepresentation of op-eds written by consultants.

Furthermore, the results show that the op-eds address issues related to a variety of socially desirable values, such as improved democracy, the value to society of PR, ethical conduct, improved working conditions and so on, which illustrates an impression management tactic directed at external as well as internal audiences (Ashforth and Kreiner, 1999). In that sense, PR professionals, or PR consultants more specifically, tend to make use of cardinal societal values in order to displace and differentiate themselves from the taint associated with the occupation.

According to a study about identity issues in the investment-banking sector, making money is an important mediator for making sense of the need to provide a professional performance. The authors of that study also discuss how being well paid can be central for identity purposes, like exhibiting status, distinctiveness, or unique qualities (Alvesson and Robertson, 2015). The results from this study show that the matter of pay is indeed seen as a status raising issue. The issue, however, is opposed by actors who emphasize the injustice of focusing on higher hourly rates since it limits the accessibility of PR services for clients with lesser resources. Accordingly, there is an interesting paradox from the viewpoint of occupational branding and professionalization. For example, dumping prices in order to win big contracts in competition with other PR agencies is not beneficial for the greater good of society but can result in lower quality and offset professionalization. However, raising hourly rates in general might perpetuate the image of PR agencies as a mainly market-driven service that only resourceful organizations can afford. In some respects, the discussion about money and working hours can be dismissed as a tempest in a teacup, but it also symbolizes some of the core issues in terms of the value of PR.

The professionalization of PR entails both a pay that equals the unique qualities and services that PR claims to deliver, as well as serving the public interest and contributing to democracy and paving way for the collective mobility and social advancement of the occupation (Bolton and Muzio, 2008). On the other hand, the call for higher wages can be interpreted as indicating greediness and elitism, which are values that the practitioners 
probably want to avoid, image wise. The intention of the op-eds calling for higher wages and fewer working hours is, however, to question an occupational culture where agencies are devaluing PR by dropping hourly rates in order to win contracts and promoting an unhealthy occupational culture where extensive overtime is sanctioned. Nevertheless, extrinsic rewards like pay and hygiene factors like working hours can serve as an external justification, in the sense that they compensate for the stigmatized work. But, at the same time, high extrinsic rewards may undermine attempts to find intrinsic rewards (Ashforth and Kreiner, 1999). From an occupational branding perspective, emphasizing extrinsic rewards may signal a lack of intrinsic value and hence deepen the perception of PR as morally tainted. The issue of pay and hourly rates can also be described as a paradox for the practitioners. A paradox is constructed when thoughts, actions, and emotions that seem logical in isolation are juxtaposed and appear as mutually exclusive (Downs et al., 2006). A way of working through this paradox for PR may be to acknowledge the stigma that stands in the way of finding common ground when it comes to discussing extrinsic awards.

Over the past decades, the Swedish political system has undergone some major change from where interest groups were represented in government bodies to a more liberal market-oriented society where interest groups now have to seek influence through lobbying or the mass media (Johansson and Larsson, 2015). Perhaps the fact that interest groups historically have been able to make their voices heard through representation in government bodies, fuels the discussion about how all organizations should be able to afford PR work, since it is a democratic right. Another distinctive feature of the Swedish PR industry is that work started within state authorities, and the occupation grew in line with the development of the governmental sector (Larsson, 2006), and the growing market orientation of PR work might result in greater suspicion and critique from the public and the media. In that regard, stigma experienced by PR practitioners in Sweden might differ from other contexts due to system of government and the historical development of occupations.

Within the Swedish context, the question about transparency and lobbying is arguably the most prone to tensions and struggles within the occupational group. The transparency issue represents a watershed issue and an unsolved tension that provides actors with a setting through which to position themselves in a favorable position. The dominant discourse in the material about transparency, despite disagreements on some issues, is that there is a need for more transparency. Against the background of an absent counter-discourse on transparency in the material, the pro-transparency writings can be interpreted as a way of challenging the non-present dominant discourse that supports less openness. Over time, the challenging discourses can, according to Ashcraft (2007), produce new occupational identities. The transparency issue can, however, also be interpreted as a double bind (e.g. Bateson et al., 1963), where the question cannot be confronted or resolved, but there is also no option of just dropping out of the discussion.

The notion of stigmatized tasks seems only to be partially valid for PR given the argument that PR can be identified as suffering from a compartmentalized stigma (Kreiner et al., 2006). The empirical material of this study shows that PR consultants identify themselves as dealing with tainted work, and some tasks, like public affairs or lobbying, are more tainted than others. This suggests, however, that PR practitioners 
working within organizations are not dealing with tainted work in the same way as consultants. In that sense, the occupational dirt of PR consultants in Sweden is far more deep and broad than what it is for PR practitioners working in organizations, and the dynamics of the stigma become much more intense for consultants. Given the wide attention in the empirical material to the issue of transparency in relation to public affairs, this can be identified as a tainted component that is salient to the public. But, at least in Sweden, this component is predominantly associated with the work of PR consultants. According to Kreiner et al. (2006), the external threat to occupations that are characterized by a compartmentalized stigma is rather mild, because of the low breadth. This results in a low driving force for the occupation to form a coherent unity and the defenses will be individualistic rather than shared. The empirical material illustrates how, for example, the issue of transparency is addressed from several different perspectives, without any genuine intention of developing a shared understanding or solution to the problem. Yeomans (2014) means that identity in PR is not fixed, but negotiated through relational performances in response to social and cultural expectations and that the professionalization of $\mathrm{PR}$ is a masculine cultural project, where professional (or masculine) attributes are emphasized in order to reject the fluffy stereotype of PR. Adding to this argument, the present study shows that the identity of PR is indeed not stable but negotiated in response to expectations. This study, however, also highlights that individual actors or agencies use rhetorical identity management and professionalization strategies in order to build or promote their own brand. Furthermore, 46 of the op-eds are written by men, 16 by women, and 23 are signed by both men and women, which reinforces the notion of men fronting the occupation (L'Etang, 2015) and the reinforcement of gender stereotypes or masculine attributions (L'Etang, 2015; Yeomans, 2010, 2014). Also, according to Kreiner et al. (2006), the most common defense tactic for occupations with compartmentalized stigmas is to refocus and create a distance to the tainted tasks. This strategy is also present in the material. However, maybe even more so, the strategy used in the op-eds is to distinguish certain actors' bad judgment or lack of ethics from the industry in general or from how the author of the op-ed thinks work should be performed.

\section{Conclusion}

To reiterate, the purpose of this study was to explore the occupational branding of PR and the management of tainted work through an analysis of op-eds authored by PR practitioners. The study took its starting point in three research questions related to the occupational branding of PR. First, a question about dilemmas and tensions occurring in relation to the occupational branding was asked in order to find out more about these tensions as well as about which actors engaged with them. Second, a question about the ways in which PR practitioners assign meaning to their work was asked, in order to explore the ways in which PR is branded in op-eds. Third, the management of the occupation's moral taint was addressed through the third question in order to explore the strategies that are used to manage the moral taint associated with the occupation. The chosen approach offered the possibility of engaging these questions and to address the professionalization of PR in a partly novel theoretical way. 
Considering the professionalization of PR as a branding endeavor of a morally tainted occupation contributes to the understanding of how inhabited and perceived moral taint interferes with the development of a shared understanding of an occupational identity - the occupational brand of PR. It also shows that some tasks and roles can be seen as more morally tainted than others.

Dilemmas and tensions affect the ways in which occupational identities are constructed (Meisenbach, 2008). In the case of PR, the process of professionalization can potentially move forward but also be reversed due to these dilemmas and tensions. As competing directions create push-pull dilemmas for practitioners when they are exposed to, for example, influences from within the occupation at the same time as they are exposed to influences from society, occupational identities are negotiated and develop over time. This study shows that practitioners perceive that there are many myths and misunderstandings surrounding PR work, such as, for example, suspicions of hidden processes, activities, and agreements with ulterior motives. In terms of occupational branding and professionalization, the absence of clarity surrounding the role of PR creates uncertainties for both practitioners within the occupation and for the public understanding of the role and influence of PR work. The absence of op-eds from, for example, the Association of Public Relations Consultancies in Sweden and from some of the most sizable and well-established agencies add to the image of tensions and power games being played by actors with different incentives and stakes.

The struggle or contest over the meaning of work (Ashcraft, 2013; Ashcraft et al., 2012) among PR practitioners features power games played by actors from different subgroups, where influential actors take the opportunity to set the agenda for industry discussions. One strategy that PR practitioners use to assign meaning to work is by aspiring to higher societal values. The acknowledgment of socially desirable values can, according to Ashforth and Kreiner (1999), be interpreted as an impression management tactic directed at external audiences, since the social approval of an occupation is dependent on the social identities associated with the occupation (Ashcraft, 2013; Phelan and Kinsella, 2009). An occupation is constructed and enacted through communication processes (Ashcraft, 2007), and discourses about what it means to be part of an occupation are reproduced through communication. In that sense, op-eds aspiring to higher societal values can be seen as an attempt to challenge dominant discourses about the moral taint associated with PR through counter-discourses that over time can produce a new occupational identity.

PR practitioners also manage the taint associated with their occupation and identity by separating tainted work from the occupational group in general. Ethical misconduct and unprofessional behavior is identified as the doings of individuals, and is presented as not being representative of the whole occupation. According to Kreiner et al. (2006), occupations that suffer from compartmentalized stigmas label tainted tasks as separate from the overall occupation, which distances the practitioners from the tainted task rather than from the occupation itself. The results from this study, however, show that practitioners distance themselves from specific individuals and agencies more than from the tainted tasks. In terms of distancing themselves from tainted tasks, the practitioners try to find a way of refocusing or recasting the tainted tasks by explaining that there are many misunderstandings about the nature of PR work. 
A branding perspective on the professionalization of PR contributes to our knowledge about how occupational identities are constructed through communicative strategies that are aimed at improving the image of tainted occupations. The result of PR work is often visible to the public through, for example, the media accounts of it.

Analyzing the professionalization of PR as a process of occupational branding and the management of tainted work opens up several suggestions for future research. First, the concept of occupational branding (Ashcraft et al., 2012) can be applied to PR in terms of, for example, studying the inclusivity-exclusivity dialectic, where exclusivity is expressed through, for example, knowledge-claims, boundary setting against neighboring knowledge-fields, and status seeking and inclusion is expressed by, for example, an expansion of the services provided by PR professionals, expanding onto other fields of knowledge or areas occupied by other occupations. Second, analyzing PR as a morally tainted occupation opens up for research that addresses the strategies in use for dealing with the tainted work associated with the occupation. The results from this study show that there are tasks and groups of practitioners that are associated with morally tainted work to a larger extent than others, but more research is needed to assess if this argument holds beyond the op-eds analyzed here. The construction of PR identities can thus be investigated, by, for example, looking at job descriptions, more media outlets, or forums where practitioners communicate about their work.

One limitation of this study is that op-eds represent a type of text that is supposed to evoke debate and discussion and not primarily show agreement on an issue. Despite this limitation, op-eds represent a piece of the occupational identity puzzle where core issues related to the occupation play out over time. Another limitation of this study is that it only represents a fraction of the agenda setting engaged in by PR actors in Sweden. The absence of op-eds from professional organizations and some of the largest and most influential PR agencies, as well as PR practitioners employed within organizations, may affect the significance of the results. Furthermore, the overrepresentation of consultants results in a misrepresentation of the whole industry. This overrepresentation can be interpreted as being inherent in the nature of the morally tainted work associated with the occupation, but it also limits the validity when it comes to talking about occupational branding strategies of the occupation in general.

Finally, this study is based on the stigma experienced by PR practitioners in Sweden, and this situation might play out differently in other contexts depending on social, political, and social systems and historical developments of the occupation. This, however, opens up for research challenging and developing the notion of PR as a tainted occupation, how meaning is ascribed to work and how professionalization of PR is branded in different contexts.

\section{Funding}

The author(s) received no financial support for the research, authorship, and/or publication of this article.

\section{References}

Alvesson M (2000) Social identity and the problem of loyalty in knowledge-intensive companies. Journal of Management Studies 37(8): 1101-1124. 
Alvesson M (2013) The Triumph of Emptiness: Consumption, Higher Education, and Work Organization. Oxford: Oxford University Press.

Alvesson M and Robertson M (2015) Money matters: Teflonic identity manoeuvring in the investment banking sector. Organization Studies 37(8): 7-34.

Andriopoulos C and Lewis MW (2009) Exploitation-exploration tensions and organizational ambidexterity: Managing paradoxes of innovation. Organization Science 20(4): 696-717.

Ashcraft KL (2007) Appreciating the 'work' of discourse: Occupational identity and difference as organizing mechanisms in the case of commercial airline pilots. Discourse \& Communication 1(1): 9-36.

Ashcraft KL (2013) The glass slipper: 'Incorporating' occupational identity in management studies. Academy of Management Review 38(1): 6-31.

Ashcraft KL, Muhr SL, Rennstam J, et al. (2012) Professionalization as a branding activity: Occupational identity and the dialectic of inclusivity-exclusivity. Gender, Work \& Organization 19(5): 467-488.

Ashforth BE and Kreiner GE (1999) 'How can you do it?': Dirty work and the challenge of constructing a positive identity. Academy of Management Review 24(3): 413-434.

Ashforth BE and Kreiner GE (2014) Dirty work and dirtier work: Differences in countering physical. Social, and Moral Stigma Management and Organization Review 10(1): 81-108.

Bateson G, Jackson DD, Haley J, et al. (1963) A note on the double bind - 1962. Family Process 2(1): 154-161.

Bolton S and Muzio D (2008) The paradoxical processes of feminization in the professions: The case of established, aspiring and semi-professions. Work, Employment \& Society 22(2): 281299.

Cornelissen JP, Haslam SA and Balmer JM (2007) Social identity, organizational identity and corporate identity: Towards an integrated understanding of processes, patternings and products. British Journal of Management 18(1): 1-16.

Downs A, Besson D, Louart P, et al. (2006) The social construction of organizational change paradoxes. Journal of Organizational Change Management 19(4): 491-502.

Drew SK, Mills M and Gassaway BM (2007) Dirty Work: The Social Construction of Taint. Waco, TX: Baylor University Press.

Edwards L (2008) PR practitioners' cultural capital: An initial study and implications for research and practice. Public Relations Review 34(4): 367-372.

Edwards L (2009) Symbolic power and public relations practice: Locating individual practitioners in their social context. Journal of Public Relations Research 21(3): 251-272.

Edwards L and Pieczka M (2013) Public relations and 'its' media: Exploring the role of trade media in the enactment of public relations' professional project. Public Relations Inquiry 2(1): $5-25$.

Fairhurst GT and Putnam L (2004) Organizations as discursive constructions. Communication Theory 14(1): 5-26.

Fawkes J (2012) Saints and sinners: Competing identities in public relations ethics. Public Relations Review 38(5): 865-872.

Fitch K and Third A (2010) Working girls: Revisiting the gendering of public relations. Prism 7(4): 1-13.

Fitch K and Third A (2013) Ex-journos and promo girls: Feminization and professionalization in the Australian public relations industry. In: Daymon C and Demetrious K (eds) Gender and Public Relations: Critical Perspectives on Voice, Image and Identity. London: Routledge, pp.247-268.

Fitch K, James M and Motion J (2016) Talking back: Reflecting on feminism, public relations and research. Public Relations Review 42(2): 279-287. 
Fitzpatrick K and Bronstein C (2006) Ethics in Public Relations: Responsible Advocacy. Thousand Oaks, CA: Sage.

Fitzpatrick K and Gauthier C (2001) Toward a professional responsibility theory of public relations ethics. Journal of Mass Media Ethics 16(2-3): 193-212.

Frandsen F and Johansen W (2010) Strategy, management, leadership, and public relations. In: Heath RL (ed.) The Sage handbook of public relations. Thousand Oaks, CA: Sage, pp.293306.

Fürsich E (2009) In defense of textual analysis: Restoring a challenged method for journalism and media studies. Journalism Studies 10(2): 238-252.

Grunig JE (2000) Collectivism, collaboration, and societal corporatism as core professional values in public relations. Journal of Public Relations Research 12(1): 23-48.

Grunig JE (2006) Furnishing the edifice: Ongoing research on public relations as a strategic management function. Journal of Public Relations Research 18(2): 151-176.

Holtzhausen DR (2000) Postmodern values in public relations. Journal of Public Relations Research 12(1): 93-114.

Holtzhausen DR and Voto R (2002) Resistance from the margins: The postmodern public relations practitioner as organizational activist. Journal of Public Relations Research 14(1): 57-84.

Hughes E (1951) Work and the self. In: Rohrer J and Sherif M (eds) Social Psychology at the Crossroads. New York: Harper \& Brothers, pp.313-323.

Hughes E (1958) Men and Their Work. New York: Free Press.

Hughes E (1962) Good people and dirty work. Social Problems 10(1): 3-11.

Ihlen $\varnothing$ (2007) Building on Bourdieu: A sociological grasp of public relations. Public Relations Review 33(3): 269-274.

Ihlen $\varnothing$ and Verhoeven P (2012) A public relations identity for the 2010s. Public Relations Inquiry 1(2): 159-176.

Jahansoozi J (2006) Relationships, transparency and evaluation: The implications for public relations. In: L'Etang J and Pieczka M (eds) Public Relations Critical Debates and Contemporary Practice. Mahwah, NJ: Lawrence Erlbaum, pp.61-91.

Johansson B and Larsson L (2015) The complexity of public relations work. Nordicom Review 36(1): 125-139.

Johansson C and Ottestig AT (2011) Communication executives in a changing world: Legitimacy beyond organizational borders. Journal of Communication Management 15(2): 144-164.

Kent ML and Taylor M (2002) Toward a dialogic theory of public relations. Public Relations Review 28(1): 21-37.

Kreiner GE, Ashforth BE and Sluss DM (2006) Identity dynamics in occupational dirty work: Integrating social identity and system justification perspectives. Organization Science 17(5): 619-636.

Larson MS (1979) The Rise of Professionalism: A Sociological Analysis. Berkley, CA: University of California Press.

Larsson L (2004) Synen på PR- och reklamkonsulter. In: Holmberg S and Weibull L (eds) Ju mer vi är tillsammans. Göteborg: SOM-intitutet, pp.81-92.

Larsson L (2006) Public relations and democracy: A Swedish perspective. In: L'Etang J and Pieczka M (eds) Public Relations Critical Debates and Contemporary Practice. London: Sage, pp.123-141.

Larsson L (2007) Public trust in the PR industry and its actors. Journal of Communication Management 11(3): 222-234.

L'Etang J (2004) Public Relations in Britain: A History of Professional Practice in the Twentieth Century. Mahwah, NJ: Lawrence Erlbaum Associates. 
L'Etang J (2006) Public relations and propaganda: Conceptual issues, methodological problems, and public relations discourse. In: L'Etang J and Pieczka M (eds) Public Relations: Critical Debates and Contemporary Practice. Mahwah, NJ: Lawrence Erlbaum, pp.23-40.

L'Etang J (2015) 'It's always been a sexless trade': 'It's clean work': 'There's very little velvet curtain' Gender and public relations in post-Second World War Britain. Journal of Communication Management 19(4): 354-370.

Luoma-aho V and Vos M (2010) Towards a more dynamic stakeholder model: Acknowledging multiple issue arenas. Corporate Communications: An International Journal 15(3): 315-331.

McDonald J (2010) Broadening CCO theory: Towards the communicative constitution of occupations. Paper presented at the 2010 NCA doctoral honors seminar, University of Utah, Salt Lake City, UT, 30 July-2 August.

McKee A (2003) Textual Analysis: A Beginner's Guide. London: Sage.

McMurray R and Ward J (2014) 'Why would you want to do that?': Defining emotional dirty work. Human Relations 67(9): 1123-1143.

Meisenbach RJ (2008) Working with tensions: Materiality, discourse, and (dis) empowerment in occupational identity negotiation among higher education fund-raisers. Management Communication Quarterly 67(2): 258-287.

Morales J and Lambert C (2013) Dirty work and the construction of identity. An ethnographic study of management accounting practices. Accounting, Organizations and Society 38(3): 228-244.

Muzio D and Tomlinson J (2012) Editorial: Researching gender, inclusion and diversity in contemporary professions and professional organizations. Gender, Work \& Organization 19(5): 455-466.

Pepper GL and Larson GS (2006) Cultural identity tensions in a post-acquisition organization. Journal of Applied Communication Research 34(1): 49-71.

Phelan S and Kinsella EA (2009) Occupational identity: Engaging socio-cultural perspectives. Journal of Occupational Science 16(2): 85-91.

Pieczka M and L'Etang J (2006) Public relations and the question of professionalism. In: Pieczka M and L'Etang J (eds) Public Relations: Critical Debates and Contemporary Practice. Mahwah, NJ: Lawrence Erlbaum, pp.265-278.

Putnam LL and Fairhurst GT (2013) Discourse analysis in organizations. In: Putnam LL and Mumby DK (eds) The New Handbook of Organizational Communication: Advances in Theory, Research and Methods (3rd edition). Thousand Oaks, CA: Sage, pp.271-296.

Putnam LL and Fairhurst GT (2015) Revisiting 'organizations as discursive constructions': 10 years later. Communication Theory 25(4): 375-392.

Putnam LL, Myers KK and Gailliard BM (2014) Examining the tensions in workplace flexibility and exploring options for new directions. Human Relations 67(4): 413-440.

Rayner C, Djurkovic N and McCormack D (2014) Who are you calling 'dirty'? Actors' and observers' perceptions of dirty work and implications for taint management. International Journal of Work Organisation and Emotion 236(2): 209-222.

Seo M, Putnam LL and Bartunek JM (2004) Dualities and tensions of planned organizational change. In: Poole MS and Van de Ven AH (eds) Handbook of Organizational Change and Innovation. New York: Oxford University Press, pp.73-107.

Strömbäck J (2008) Four phases of mediatization: An analysis of the mediatization of politics. The International Journal of Press/Politics 13(3): 228-246.

Svallfors S (2016) Out of the golden cage: PR and the career opportunities of policy professionals. Politics \& Policy 44(1): 56-73.

Tajfel H and Turner JC (1979) An integrative theory of intergroup conflict. The Social Psychology of Intergroup Relations 33(47): 74. 
Trethewey A and Ashcraft KL (2004) Special issue introduction: Practicing disorganization: The development of applied perspectives on living with tension. Journal of Applied Communication Research 32(2): 81-88.

Turner JC, Oakes PJ, Haslam SA, et al. (1994) Self and collective: Cognition and social context. Personality and social psychology bulletin 20: 454-463.

Tyllström A (2013) Legitimacy for Sale: Constructing a Market for PR Consultancy. Uppsala: Department of Business Studies, Uppsala Universitet.

Valentini C (2009) Looking for institutionalization: Italian public relations and the role of credibility and professionalism. In: Yamamura K (ed) The 12th Annual International Public Relations Research Conference, pp.553-569. Available at: http://www.instituteforpr.org/wpcontent/uploads/LookingForInstitutionalization.pdf

Van Ruler B and Verčič D (2008) Communication management in Europe - Challenges and opportunities. In: Zerfass A, Van Ruler B and Sriramesh K (eds) Public Relations Research: European and International Perspectives. Wiesbaden: VS Verlag für Sozialwissenschaften, pp.219-232.

Vásquez C, Sergi V and Cordelier B (2013) From being branded to doing branding: Studying representation practices from a communication-centered approach. Scandinavian Journal of Management 29(2): 135-146.

Verhoeven P, Zerfass A and Tench R (2011) Strategic orientation of communication professionals in Europe. International Journal of Strategic Communication 5(2): 95-117.

Yeomans L (2010) Soft sell? Gendered experience of emotional labour in UK public relations firms. PRism 7(4): 1-14.

Yeomans L (2014) Gendered performance and identity work in PR consulting relationships. In: Daymon D and Demetrious K (eds) Gender and Public Relations: Critical Perspectives on Voice, Image, and Identity. New York: Routledge, pp.87-107.

\section{Author biography}

Christina Grandien is an Assistant Professor in Media and Communication Studies at Mid Sweden University, Sweden. Her research interests include areas such as public relations and democracy, professionalization of public relations, and the value of communication for organizations. 